\title{
Concerns about bias in studies on clozapine and mortality
}

\author{
Citation for published version (APA):
}

van der Zalm, Y. C., Termorshuizen, F., \& Selten, J. P. (2019). Concerns about bias in studies on clozapine and mortality. Schizophrenia Research, 204, 425-426.

https://doi.org/10.1016/j.schres.2018.08.017

Document status and date:

Published: 01/02/2019

DOI:

10.1016/j.schres.2018.08.017

Document Version:

Publisher's PDF, also known as Version of record

\section{Document license:}

Taverne

\section{Please check the document version of this publication:}

- A submitted manuscript is the version of the article upon submission and before peer-review. There can be important differences between the submitted version and the official published version of record.

People interested in the research are advised to contact the author for the final version of the publication, or visit the DOI to the publisher's website.

- The final author version and the galley proof are versions of the publication after peer review.

- The final published version features the final layout of the paper including the volume, issue and page numbers.

Link to publication

\footnotetext{
General rights rights.

- You may freely distribute the URL identifying the publication in the public portal. please follow below link for the End User Agreement:

www.umlib.nl/taverne-license

Take down policy

If you believe that this document breaches copyright please contact us at:

repository@maastrichtuniversity.nl

providing details and we will investigate your claim.
}

Copyright and moral rights for the publications made accessible in the public portal are retained by the authors and/or other copyright owners and it is a condition of accessing publications that users recognise and abide by the legal requirements associated with these

- Users may download and print one copy of any publication from the public portal for the purpose of private study or research.

- You may not further distribute the material or use it for any profit-making activity or commercial gain

If the publication is distributed under the terms of Article $25 \mathrm{fa}$ of the Dutch Copyright Act, indicated by the "Taverne" license above, 
Letter to the Editor

\section{Concerns about bias in studies on clozapine and mortality}

In view of the high all-cause mortality among patients with schizophrenia and the wide range of positive and negative effects of clozapine, it is important to know whether the drug is associated with a differential mortality pattern in comparison to other antipsychotic drugs. Tiihonen et al. (2009) reported a significantly lowered all-cause mortality and a lowered mortality from suicide in users of clozapine. In this journal, however, de Hert et al. (2010) pointed out that several types of bias may have influenced the results. For example, the exclusion of deaths after a hospitalization of more than 2 days, so that two-thirds of deaths were not considered. Another example is survivorship bias in the analysis of death by suicide. Suicide is more common in the first years after onset of psychosis, whereas clozapine is often first prescribed years later.

The purpose of this letter is to discuss biases and methodological errors in other studies that reported a significantly decreased mortality associated with clozapine. The need to do so arose with the recent publication of a meta-analysis (Vermeulen et al., 2018), which concluded that long-term all-cause mortality was substantially lower with continuous clozapine treatment than with treatment with other antipsychotics (mortality rate ratio $=0.56 ; 95 \% \mathrm{CI} 0.36-0.85$ ). The authors used crude, unadjusted mortality rates in the meta-analysis and ignored the fact that in many of the reviewed studies there is a considerable age difference between clozapine-users and non-users (see Supplementary Table 1). The comparison of a relatively young group of clozapine-users to an older group of non-users of this drug, without adjusting for age, resulted in an overly optimistic evaluation of clozapine and an unjustified conclusion. For illustration, Supplementary Table 2 shows the large differences between the crude and the adjusted mortality rate ratios of the included studies.

Besides the study of Tiihonen et al. (2009), two other studies reported a significantly lower mortality rate with clozapine than with other antipsychotics. Hayes et al. (2015) reported a strong association between being prescribed clozapine and a lower mortality (adjusted hazard ratio $=0.4 ; 95 \% \mathrm{CI} 0.2-0.7$ ). However, the authors failed to apply a left truncation of the time between the start of follow-up (the time of diagnosis) and when clozapine was started. Therefore, the patient was not observable for risk of death in this period implying long periods necessarily without any observed death event ('immortal time bias').

Perhaps the best study in this area was conducted by Walker et al. (1997). They compared episodes of clozapine use to episodes after discontinuation of this drug and divided the time period after discontinuation into episodes of "recent use" (up to 3 months after discontinuation) and episodes of "past use" (more than three months later). All-cause mortality was significantly lower during episodes of use than during episodes of past use. It was highest during episodes of recent use, probably because moribund patients were taken off the drug. An impressive finding was the lower risk of suicide during current use than during past use (standardized mortality ratio $=0.17 ; 95 \% \mathrm{Cl} 0.10-0.30$ ). Nevertheless, the study was limited by its design (one would have preferred a comparison of clozapine users to treatment-resistant patients who do not receive this drug) and the lack of information on the reasons why clozapine was discontinued and the pharmacotherapy after this discontinuation.

New large-scale and long-term studies are needed that take important forms of bias into account. In order to avoid the risk of survivorship bias, we recommend the use of incidence cohorts, especially if death by suicide is to be investigated. As to confounding by indication, new studies should take into account that clozapine might be prescribed more often to relatively healthy patients, and that the intensive monitoring of patients may lead to better somatic treatment. It is also worthwhile to note that the inclusion of individuals who do not use any antipsychotic affects the results. Wimberley et al. (2017) found a significantly higher adjusted hazard ratio for all-cause mortality among clozapine non-users ( $\mathrm{HR}=1.84 ; 95 \% \mathrm{CI} 1.13-3.01)$. However, after distinguishing between users and non-users of antipsychotics, the hazard ratio for allcause mortality was no longer significantly higher among users of other antipsychotics ( $\mathrm{HR}=1.41 ; 95 \% \mathrm{Cl} 0.83-2.40$ ) whereas it was significantly higher among non-users of antipsychotics (HR $=2.46$; $95 \% \mathrm{CI}$ 1.46-4.14).

The good news, despite all these caveats and criticisms, is that to the best of our knowledge no study has reported a significantly increased mortality among clozapine users. Thus, it is possible that the marked therapeutic effect of clozapine outweighs the negative effects of metabolic and other side effects. Indeed many patients report that they have finally found peace after years of agony and it is conceivable that this decrease in stress is of crucial importance.

\section{Conflict of interest}

The authors declare that there are no conflicts of interest

\section{Contributors}

Author YZ wrote the first draft of the letter. All authors contributed to and have approved the final letter.

\section{Acknowledgement}

None.

\section{Appendix A. Supplementary data}

Supplementary data to this article can be found online at https://doi. org/10.1016/j.schres.2018.08.017.

\section{References}

De Hert, M., Correll, C.U., Cohen, D., 2010. Do antipsychotic medications reduce or increase mortality in schizophrenia? A critical appraisal of the FIN-11 study. Schizophr. Res. 117, 68-74. 
Hayes, R.D., Downs, J., Chang, C.K., Jackson, R.G., Shetty, H., Broadbent, M., Hotopf, M. Stewart, R., 2015. The effect of clozapine on premature mortality: an assessment of clinical monitoring and other potential confounders. Schizophr. Bull. 41, 644-655.

Tiihonen, J., Lonnqvist, J., Wahlbeck, K., Klaukka, T., Niskanen, L., Tanskanen, A., Haukka, J., 2009. 11-year follow-up of mortality in patients with schizophrenia: a populationbased cohort study (FIN11 study). Lancet 374, 620-627.

Vermeulen, J.M., Van Rooijen, G., Van de Kerkhof, M.P.J., Sutterland, A.L., Correll, C.U., De Haan, L., 2018. Clozapine and long-term mortality risk in patients with schizophrenia: a systematic review and meta-analysis of studies lasting 1.1-12.5 years. Schizophr. Bull. https://doi.org/10.1093/schbul/sby052.

Walker, A.M., Lanza, L.L., Arellano, F., Rothman, K.J., 1997. Mortality in current and former users of clozapine. Epidemiology 8, 671-677.

Wimberley, T., MacCabe, J.H., Laursen, T.M., Sorensen, H.J., Astrup, A., Horsdal, H.T., Gasse, C., Stovring, H., 2017. Mortality and self-harm in association with clozapine in treatment-resistant schizophrenia. Am. J. Psychiatry 174, 990-998.

Y.C. van der Zalm

Rivierduinen Institute for Mental Health, Sandifortdreef 19, $2333 Z Z$ Leiden,

the Netherlands

Maastricht University Medical Center, Dept. of Psychiatry \& Neuropsychology, School for Mental Health and Neuroscience, PO Box 616, 6200 MD Maastricht, the Netherlands Corresponding author at: Sandifortdreef 19, 2333 ZZ Leiden, the Netherlands. E-mail address: y.vanderzalm@rivierduinen.nl.
F. Termorshuizen Rivierduinen Institute for Mental Health, Sandifortdreef 19, $2333 Z Z$ Leiden, the Netherlands

J.P. Selten

Rivierduinen Institute for Mental Health, Sandifortdreef 19, $2333 Z$ Z Leiden, the Netherlands Maastricht University Medical Center, Dept. of Psychiatry \& Neuropsychology, School for Mental Health and Neuroscience, PO Box 616, 6200 MD Maastricht, the Netherlands

20 July 2018 